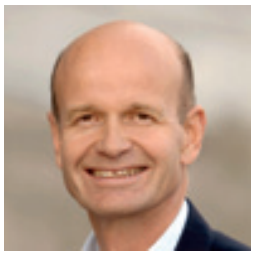

\title{
Irregulære migranter har rettigheter i Norge
}

\section{Norge finnes det rundt 18000 irregulære migranter. De har ikke lov til å oppholde seg i landet, men har allikevel krav på å få et helsetilbud når de trenger det. Samarbeid og frivillighet må stå sentralt når vi nå skal gi et tilbud til disse.}

Selv om disse menneskene oppholder seg ulovlig her i landet, er de beskyttet gjennom internasjonale konvensjoner om menneskerettigheter som Norge har forpliktet seg til å oppfylle. Erfaring viser likevel at personer som oppholder seg ulovlig i landet, ofte ikke får oppfylt sine grunnleggende menneskerettigheter - som tilgang til helsehjelp og stønad til mat og varme klær. Røde Kors har derfor det siste året satt fokus på hvordan Norge bør styrke rettighetene til de irregulære migrantene.

Norge har ratifisert både den europeiske menneskerettighetskonvensjonen og FNs konvensjon om økonomiske, sosial og kulturelle rettigheter og har gitt disse forrang fremfor norsk lov gjennom menneskerettsloven. Dette innebærer blant annet at medlemsstatene må sikre et forsvarlig helsetilbud til irregulære migranter, særlig til sårbare grupper som barn, funksjonshemmede, gravide og eldre.

I Sverige har organisasjonene som driver helsetilbud for irregulære migranter gått sammen om et «rett til helsehjelp»-initiativ, der de med et felles budskap fronter denne gruppens rettigheter overfor myndighetene. Vi er avhengige av at vi samarbeider godt og hjelper hverandre med å rekruttere fri- villige som kan bidra til at de menneskene vi snakker om, får det tilbudet de har krav på. Selv om irregulære migranter som oftest får oppfylt behovet for øyeblikkelig hjelp, er Røde Kors likevel kjent med at de kan møte på utfordringer når de forsøker å få nødvendig helsehjelp. Dette skyldes blant annet at dere leger som yter nødvendig helsehjelp til irregulære migranter, møter på vanskeligheter når dere skal kreve refusjon fra trygdeetaten for utgifter knyttet til slik hjelp. Et refusjonskrav er nemlig betinget av at pasienten er medlem av folketrygden og har personnummer. Siden det kun er mennesker med lovlig opphold i Norge som kan bli medlemmer av folketrygden, får irregulære migranter liten nytte av sin rett til nødvendig helsehjelp når de verken kan bli med i folketrygden eller har personnummer.

Sosialtjenesteloven skal sikre at ingen sulter eller fryser i hjel i Norge. Denne loven omtales ofte som «samfunnets siste sikkerhetsnett», nettopp fordi den skal fange opp alle som befinner seg på norsk territorium og selv ikke klarer å sørge for sitt livsopphold. Til tross for dette gjelder sosialtjenesteloven i dag kun for dem som har «lovlig opphold» i Norge. På grunn av en økning i antall søknader fra irregulære migranter skrev Arbeids- og inkluderingsdepartementet likevel et brev til alle landets kommuner i 2004 hvor de presiserer at sosialtjenesten «må yte livsnødvendig hjelp i en akutt krisesituasjon, også til personer uten lovlig opphold». I 2008 startet Amnesty, Gatejuristen, Juss-Buss og Røde Kors et prosjekt som tar sikte på å informere irregulære migranter om deres rett til matpenger og stønad til varme klær i nødssituasjoner. Irregulære migranter kan nå henvende seg til Gatejuristen eller JussBuss for å få oppfylt disse rettighetene.

For å sikre at humanitær assistanse til irregulære migranter ikke skal være straffbart, har Røde Kors også arbeidet for å få presisert i den nye utlendingsloven at det å yte humanitær assistanse til irregulære migranter i Norge er lovlig. Uten en slik presisering kunne man risikere at humanitære organisasjoner ikke våget å gi hjelp til irregulære migranter i frykt for å bli straffeforfulgt. Vi er derfor glade for at Justisdepartementet nå har foreslått at det åpent å tilby humanitær bistand til personer uten lovlig dokumentasjon for sitt opphold i Norge ikke er straffbart. Dette betyr blant annet at Røde Kors og Kirkens Bymisjon kan starte et helsetilbud for irregulære migranter uten å risikere straffeforfølging.

For Røde Kors handler rettferdighet og likhet ikke bare om hva som står skrevet i konvensjoner, det handler vel så mye om faktiske handlinger. Skal Norge kunne leve opp til de verdier som lå til grunn for verdenserklæringen i 1948 nytter det ikke å tro at jobben er gjort ved ratifiseringen av ulike menneskerettighetskonvensjoner. Reglene må også følges. For Røde Kors er det å dekke behov vi ser oppstå det viktigste lover og rettigheter er virkemidler som hjelper oss å hjelpe. Det viktigste vi kan gjøre nå, er å hjelpe dem som trenger det!

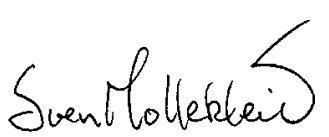

Ungdom og legemidler

Nevrofibromatose

- Benigne gynekologiske tilstander
Legen og flyktningpasienten

Nevroendokrine svulster

Infeksjon med fusobakterier 